\title{
Application of geophysical methods for the subsurface treatment of the Piekary highway junction in shallow mining terrain
}

\author{
Zenon Pilecki* \\ Mineral and Energy Economy Research Institute of the Polish Academy of Sciences, Cracow, Poland
}

\begin{abstract}
The study presents the application of geophysical methods in the subsurface treatment of the A-1 highway in the area of the Piekary junction in the terrain of historic zinc and lead ore mining, in the northern part of the Upper Silesian Coal Basin in Poland (USCB). The study area was under threat of discontinuous deformations, mainly sinkholes. This threat resulted from the shallow exploitation of zinc and lead ores, as well as contemporary exploitation of coal seams at greater depths. An original methodology of subsurface treatment has been developed as an adaptation to the geophysical measurement results. The methodology uses the gravimetric method at the initial and final control stages, as well as the seismic and borehole georadar methods during the detailed evaluation stage. The results of the study allowed different categories of sinkhole hazard to be determined in the area of the Piekary junction. The scope of the liquidation works was selected to match the hazard levels. Blasting of varying intensities and the borehole injection of the filling material were performed. The combination of substrate treatment methodologies and highway construction protection systems have proved to be effective.
\end{abstract}

Keywords: shallow mining, deep mining, discontinuous deformations, subsurface treatment, geophysical methods

\section{Introduction}

The construction of transport routes and other facilities in post-mining areas often calls for subsurface treatment [1-6]. The effectiveness of the subsurface treatment depends to a large extent on the correct recognition of the hazard degree in terms of the occurrence of discontinuous deformations on the terrain surface $[1,5-6]$. Various methods are used for this purpose as part of geophysical and geological-engineering [7-19].

The aim of the study is to present a method of using geophysical methods in subsurface treatments at the Piekary junction of the A-1 highway in a highly destructed mining area in the Upper Silesian Coal Basin (USCB) (Fig. 1). The study presents the methodology of the subsurface treatment applied in 2009-2010. The sinkhole hazard in this area results from the historical shallow exploitation of zinc and lead ores, as well as the historical and contemporary deep exploitation of hard coal seams [5]. In the geological and engineering

\footnotetext{
*Corresponding author: pilecki@meeri.pl
} 
conditions of the Piekary highway junction, the main geophysical assessment methods used to evaluate the sinkhole hazard were gravimetry, borehole georadar (GPR) and a seismic profiling.
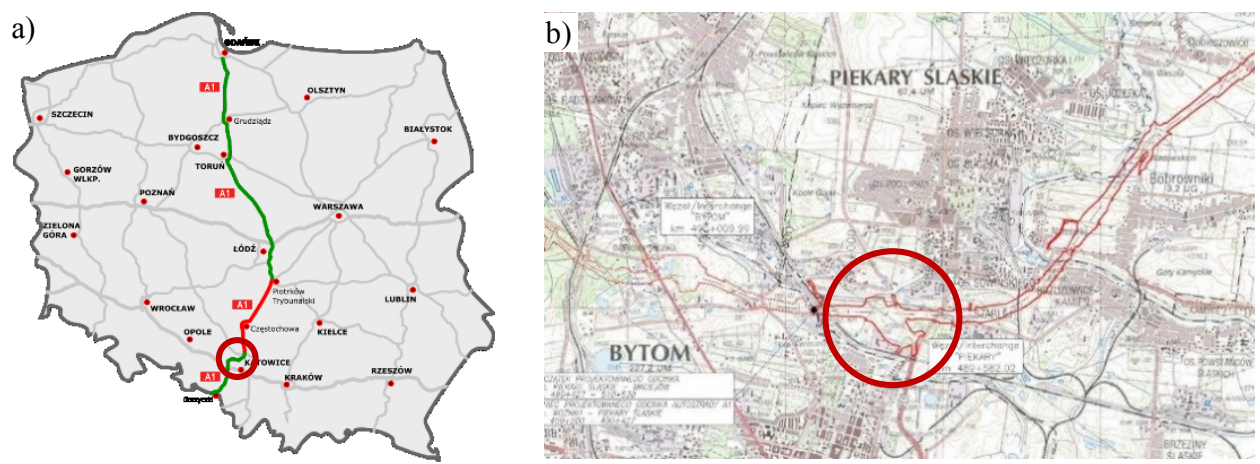

Fig. 1. Location of Piekary highway A-1 junction; the red circle denotes research terrain (GDDKiA data [20]).

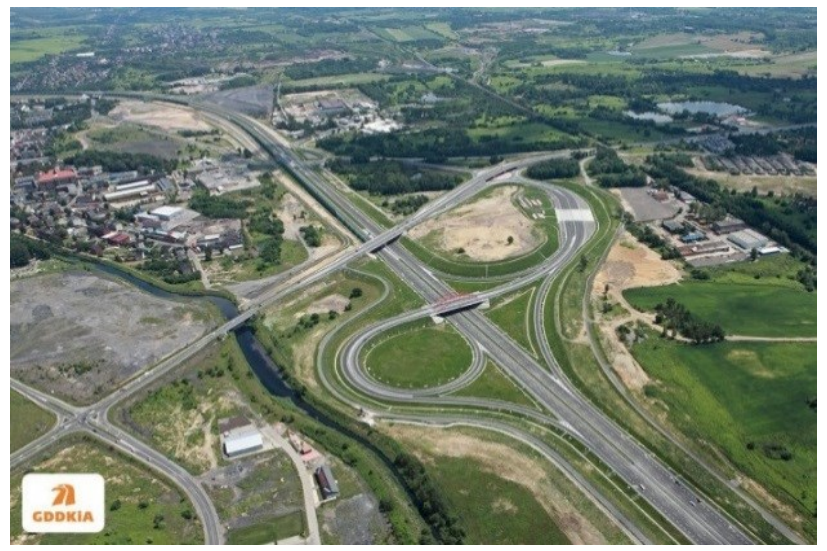

Photo. 1. A view of Piekary junction on highway A-1, constructed on complicated mining terrain (GDDKiA data [20]).

\section{Geological and mining conditions}

The Piekary junction area is located in the Bytom Basin, within the USCB. The geological structure of the area is complex, with Carboniferous, Triassic, Tertiary (Neogene), Quaternary and anthropogenic deposits [5].

In the study area, the Carboniferous deposits occur at a depth greater than about $180 \mathrm{~m}$, and are represented by claystones, mudstones, sandstones and coal seams. The Triassic deposits lie inconsistently on the folded and faulted Carboniferous deposits, and are mainly represented by ore-bearing dolomites and limestone. In the area of the Piekary junction, these deposits are almost horizontal, with a several-degree inclination to the south. In the area of the city of Piekary are outcrops of Triassic formations of the northern part of the Bytom Basin. Neogene formations occur locally and fragmentarily in the erosive depressions of the Triassic basement. They are represented by marly clays or sands. Quaternary formations occur mostly in the form of clays, various types of glacial and river sands and gravels. They occur on most of the terrain except for the hills, where Triassic formations are revealed. 
In the Carboniferous deposits, throughout the area of the Piekary junction, is the Radzionkowski fault zone with a throw of about $180 \mathrm{~m}$ (direction NNW-SSW). The Radzionkowski fault reveals itself in the Triassic formations, where it reaches a throw of about 5 to $20 \mathrm{~m}$. This fault zone features seismic tremors induced by the deep exploitation of coal seams [5].

In the Bytom Basin, the Triassic formations contain deposits of zinc and lead ores at a depth of about $20 \mathrm{~m}$ in the region of outcrops of ore-bearing dolomites to a depth of about $100 \mathrm{~m}$ in the axis of the Bytom Basin in the area of the city of Bytom (Fig. 2). Their exploitation began in the 12th century. In the area of the Piekary junction, the deposits were exploited in two layers, from 2.0 to $6.0 \mathrm{~m}$ thick. During the construction of the Piekary junction, after removing the cover formations and heavily weathered Triassic layers, the upper layer was at a depth of about $40 \mathrm{~m}$.

As a result of the exploitation of metal ore deposits, many voids and loosened zones remained, which were the direct cause of the occurrence of numerous discontinuous deformations on the surface of the area, in the form of cracks, ditches and local troughs (Photo 2).

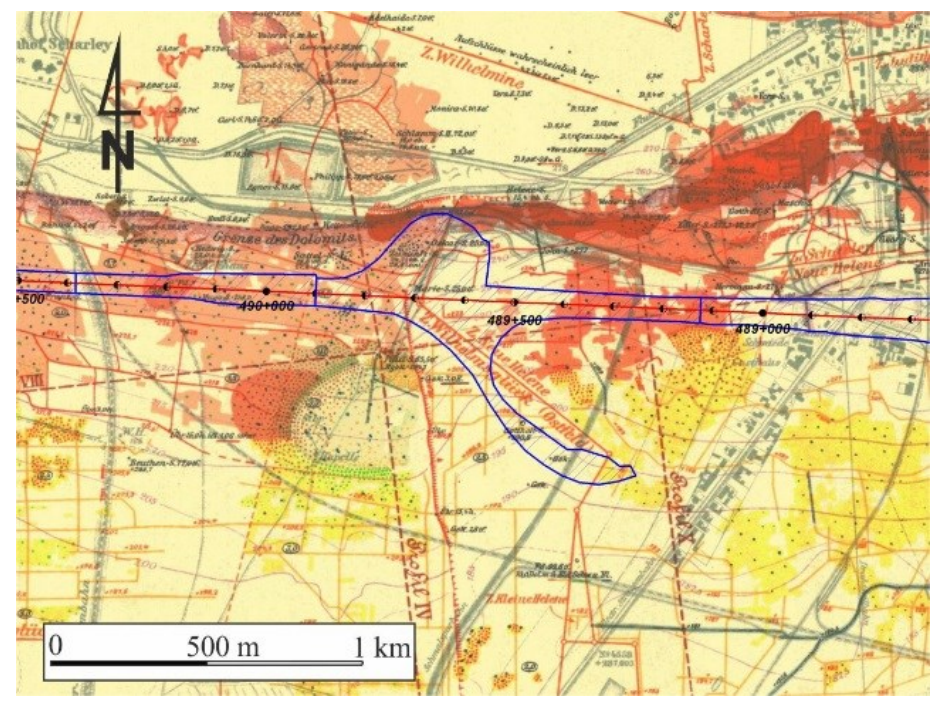

Fig. 2. Fragment of archival map showing the ore deposits: red - zinc and yellow - lead. The A-1 highway is denoted by the thick blue line [21].

The mining of coal seams in the Bytom Basin has been conducted since 1863 and continues in the present period. In the vicinity of the Piekary junction, several coal seams were exploited with a total thickness exceeding $20 \mathrm{~m}$. Deep mining caused the occurrence of continuous deformations in the form of mild and extensive subsidence troughs. As a result, this exploitation caused subsidence of the terrain surface exceeding $20 \mathrm{~m}$. Deep exploitation, which disturbed the rock mass, contributed to the reactivation of old voids and loosened zones in the areas of the historical, shallow metal ore mining.

The activation of sinkhole processes in the area of the Piekary junction is also associated with the complicated water conditions, including pumping water from the nearby Bolko shaft. Various types of seismic and paraseismic vibrations also impact the development of the deformations.

In general, in the area of the Piekary highway junction, sinkhole processes can be activated by such factors as [5]:

- historical shallow exploitation of ore deposits,

- deep exploitation of coal seams, 
- tectonic zone of the Radzionkowski fault,

- seismicity induced by deep mining,

- non-stable infiltration by rainwater,

- changes in water level due to continuous pumping in Bolko shaft,

- dynamic loads from passing heavy vehicles.
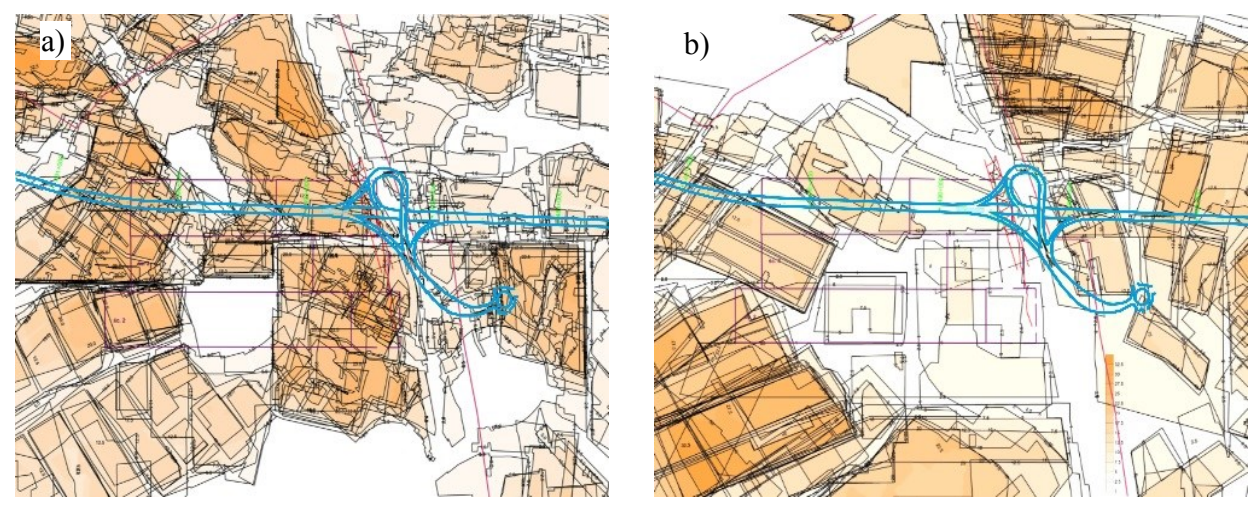

Fig. 3. Shallow exploitation of zinc ores and deep exploitation of coal seams in the area of the Piekary junction; a) for the period to 1966, b) for the period from 1966 to 2009 . The A-1 highway is denoted by the blue line (GDDKiA [20]).
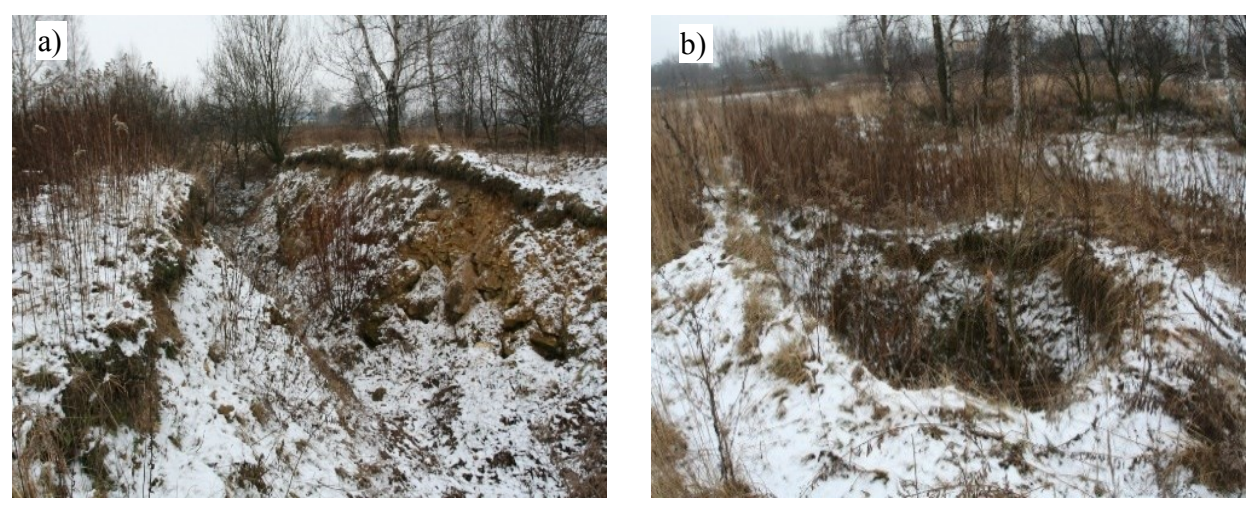

Photo. 2. Sinkholes observed on the area of the Piekary highway junction before its construction; a) sinkhole trench, b) conical sinkhole [5].

\section{Methodology}

\subsection{Concept of subsurface treatment for the Piekary highway junction area}

In the area of the Piekary junction, the exploitation of zinc and lead ore deposits was carried out in strong, grey ore-bearing dolomites. Such conditions indicate a high probability of maintaining the long-term stability of post-mining voids. However, sinkholes as a result of ore deposit mining and ditches several dozen meters long have appeared on the terrain surface as a result of the deep mining of coal seams (Photo. 2). In addition, the seismically active Radzionkowski fault runs through the area of the Piekary junction. During the construction of the Piekary junction, the 620 coal seam was extracted in its immediate vicinity.

Due to such a complicated geological and mining situation, a concept was developed to create a two layer system of different stiffnesses in the junction substrate (Fig. 4). The main 
purpose of this layer system was to protect the junction construction against discontinuous deformations and to absorb larger displacements in the rock mass at depths of more than 20 $\mathrm{m}$.

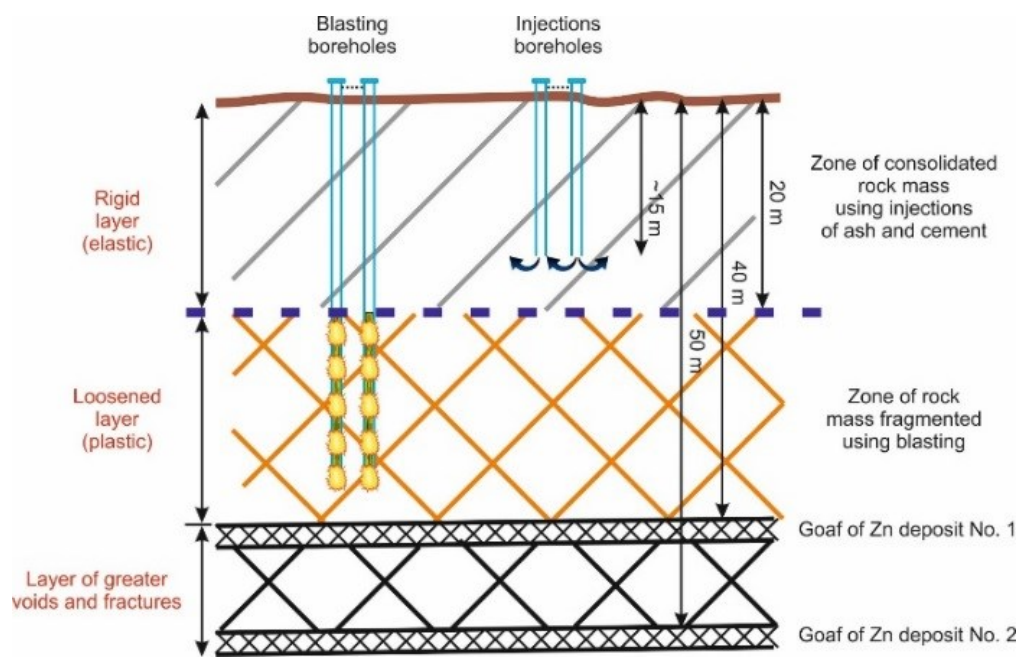

Fig. 4. A concept of subsurface treatment in the area of Piekary highway junction.

The lower layer, $20 \mathrm{~m}$ thick, located at a depth of 20 to $40 \mathrm{~m}$, acts as a layer susceptible to large deformations due to its fragmentation by means of the blasting method. This layer covers the level of ore deposit exploitation in which the sinkhole processes developed. The upper layer, $20 \mathrm{~m}$ thick, located from the terrain surface to a depth of $20 \mathrm{~m}$, acts as a layer of greater stiffness, reinforced as a result of injecting filler material with cement.

In this way, a system of two layers was created, the upper one with greater rigidity lying on the loosened lower layer. It was assumed that in the lower layer the existing voids collapsed at the time of its creation and the loosened zones were tightened in massive dolomites. In this way, the lower layer was able to absorb the displacements caused by the deep exploitation of coal seams and the activity of the Radzionkowski fault. At the same time, rock mass de-stressed by means of the blasting method reduced the potential for excessive stresses that could persist in the Radzionkowski fault zone.

\subsection{Basic stages of subsurface treatment for the Piekary highway junction with the use of geophysical methods}

The methodology of subsurface treatment of the Piekary highway junction comprised the following stages [5]:

- Stage I - analysis of archival geological-engineering and mining data, including aerial and satellite images, land mapping, and numerical analysis of rock mass deformation.

- $\quad$ Stage II - recognition of the location of sinkhole hazard zones by gravimetric and georadar methods, and seismic profiling of the border of the rock basement.

- $\quad$ Stage III - performing de-stress blasting in geophysical anomalous zones at a depth of 20 to $35 \mathrm{~m}$.

- $\quad$ Stage IV - filling of voids and loosened zones by means of injecting backfilling material with cement at a depth of up to $15 \mathrm{~m}$.

- $\quad$ Stage V - quality control of subsurface treatment using gravimetric and additional methods (GPR, seismic).

- $\quad$ Stage VI - additional injection works in stronger geophysical anomalies. 
From previous experience in the areas of shallow mining in the USCB, the gravimetric method was assumed as a basic one $[4,5]$. This is because the volumetric density is a clearly contrasting physical parameter in the tested subsurface in the mining terrain. The results of the gravimetric surveys are most often correlated with the results of refraction seismic profiling as well as, depending on the measurement conditions, the results of the borehole GPR. Figure 5 shows an example of such gravity surveys with seismic refraction profiling. The aim of the seismic surveys was to determine the course of the boundary between the overburden and rock basement, and the velocity changes of the refraction wave (Fig. 6a). Seismic refraction surveys were supported by the vertical profiling of S-wave velocity changes by the MASW method.
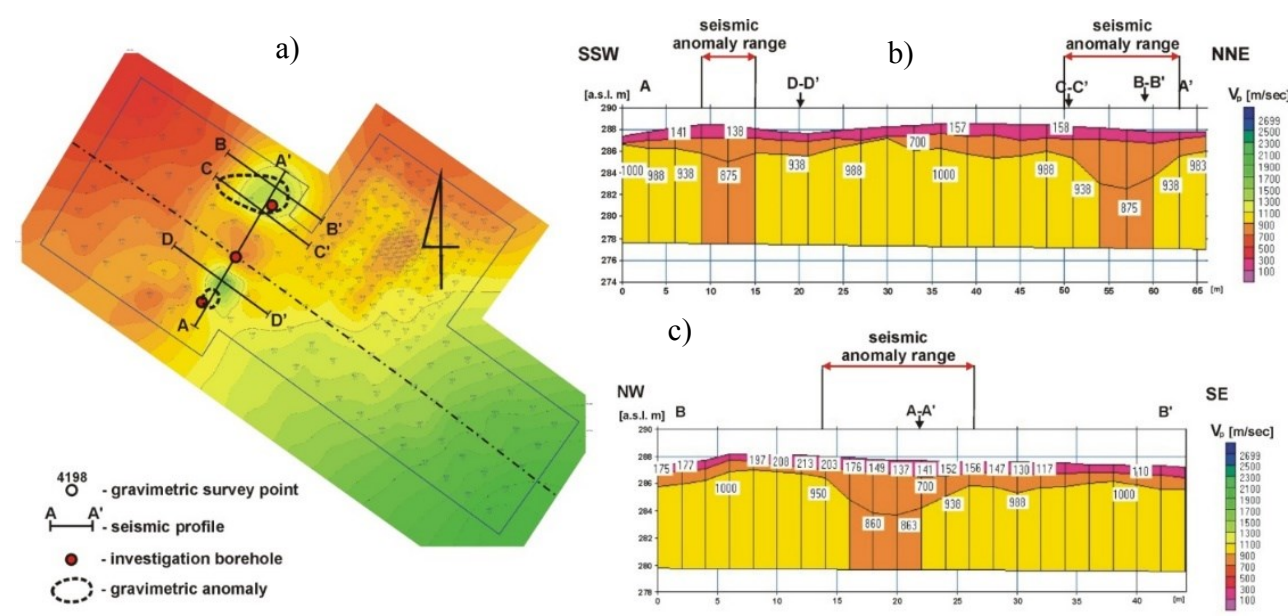

Fig. 5. An example of gravimetric surveys (a) supported by refraction seismic profiling (b, c) to recognize sinkhole hazards in the mining terrain of the Piekary highway junction [5].

Identified geophysical anomalies are often verified by borehole georadar surveys to confirm the presence of voids and loosened zones in the rock mass (Fig 6b). The results of control drilling determine the final decision on the need to apply treatment works. The seismic and borehole GPR methods are used as complementary methods, depending on the measurement conditions. These methods use other properties of the medium than the gravimetric method, which may allow for a more reliable image of the weak zones.

During the de-stress blasting, an array of seismometers were used to monitor the seismic vibrations.

Particularly, the application of geophysical methods in the treatment of subsurface on the area of Piekary junction relied on:

- determination of voids and loosened zones - their location, geometry and volume,

- $\quad$ assessment of the effectiveness of the backfilling of voids and loosened zones in the subsurface,

- location of the Radzionkowski fault zone,

- assessment of the range of destruction of the rock mass by blasting,

- assessment of harmful paraseismic vibrations,

- $\quad$ assessment of the seismic effects of the de-stress blasting. 
a)

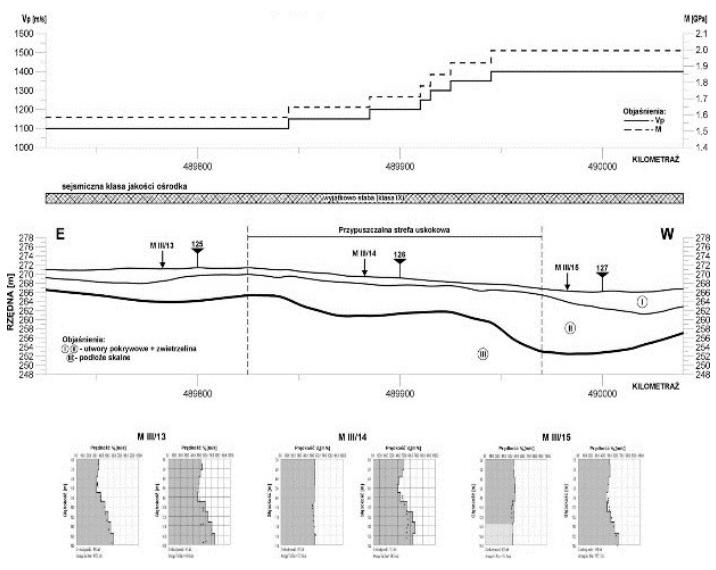

b)

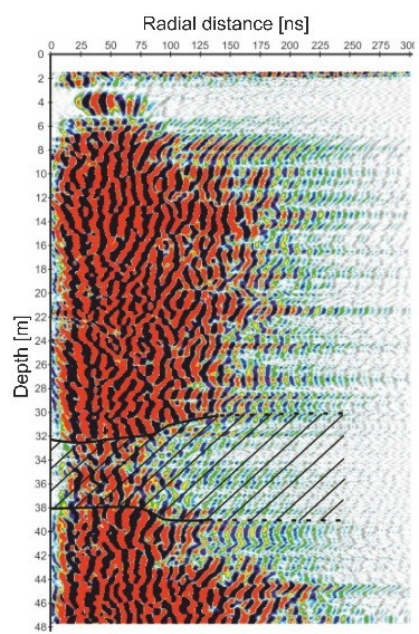

Fig. 6. Examples of seismic refraction and MASW used for profiling the border between the loosened overburden and rock basement, (a) with georadar borehole surveys to verify gravimetric anomalies (b) in the area of the Piekary highway junction [5].

\section{Results}

In order to assess the hazard of the occurrence of discontinuous deformations in the Piekary junction area, a map of the risk categories was developed (Fig. 7). It was based on the results of geophysical surveys, mainly gravimetric, and an analysis of archival geologicalengineering and mining data. The map shows four categories of sinkhole occurrence risk in the area of the construction site for the Piekary junction (Fig 7). Depending on the degree of risk, different densities of blast boreholes (Fig. 8) and, consequently, densities of injection boreholes (Fig. 7) were used.

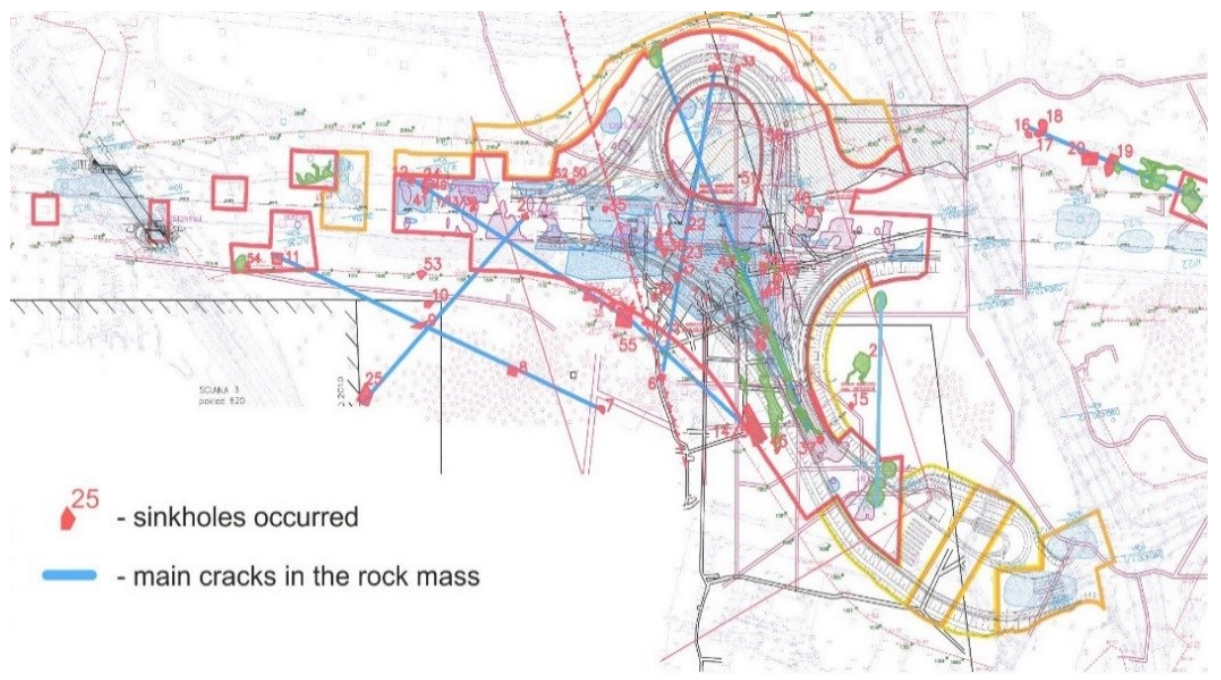

Fig. 7. The categories of sinkhole occurrence risk together with the intensity of the injection boreholes in the area of the Piekary junction. Red - category III (very high risk), orange - category II (medium risk), yellow - category I (low risk), and white - category 0 (lack of risk of sinkhole occurrence). Irregular red and green dots - archival sinkholes. See text for a broader description [5]. 
As a result of the de-stress blasting, 1836 boreholes with a total length of $48,000 \mathrm{~m}$ were blasted. In total, an explosive mass totalling $110,000 \mathrm{~kg}$ was used. The boreholes were blasted serially along the lines marked in figure 8 . This blasting arrangement was related to the numerically calculated stress isolines at the Piekary junction [20]. After the de-stress blasting, 48 new sinkholes appeared on the terrain surface (Photo. 3).

An upper layer of about $20 \mathrm{~m}$ thick was reinforced by the injection of binding material. In total, $215,385 \mathrm{~m}^{3}$ of filling material was injected into about 850 boreholes ranging from several to $15 \mathrm{~m}$ in length. The total length of the injection boreholes was $11,836 \mathrm{~m}$.

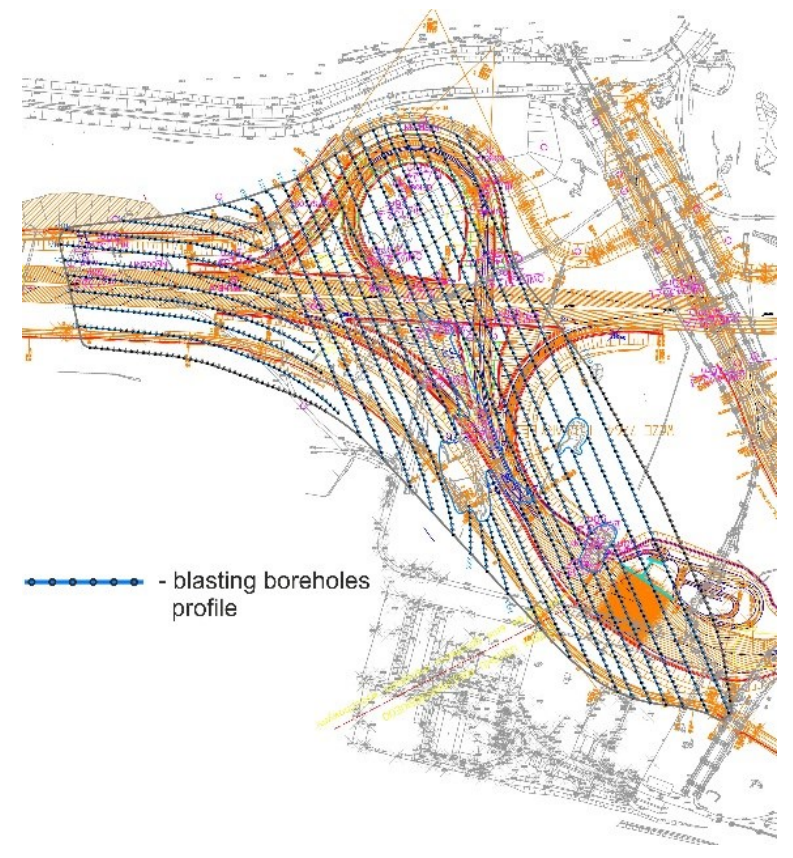

Fig. 8. Location of the blasting boreholes in the area mining terrain of Piekary junction [5].
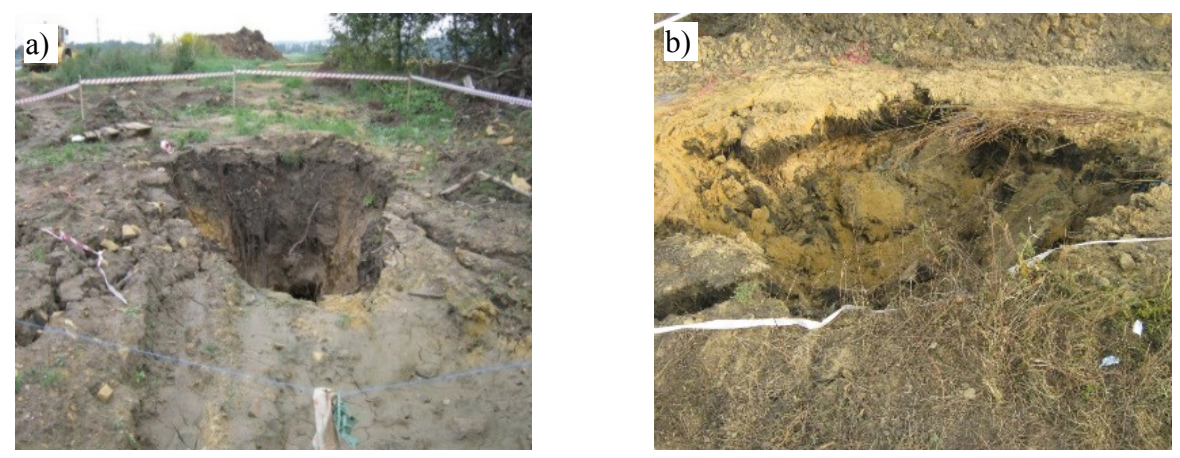

Photo. 3. Examples of sinkholes registered after de-stress blasting in the mining area of Piekary highway junction - a) and b) typical sinkholes for shallow cavities [5].

Control gravimetric measurements after finishing the substrate treatment showed significantly smaller or the disappearance of the gravimetric anomalies. The rock mass in the area of several stronger anomalies was additionally treated.

In the period from the end of the substrate treatment in 2010 to the present, no sinkhole has been recorded in the area of the treatment works at the Piekary junction. 


\section{Summary}

The study presented the methodology of substrate treatment applied at the Piekary junction of the A-1 highway, which is at high risk of discontinuous deformations. The voids and loosened zones left in the rock mass after the shallow exploitation of zinc and lead ores resulted in the development of sinkhole processes due to the impact of many geological, mining and anthropogenic factors.

The methodology of the substrate treatment applied at the Piekary junction assumed the use of geophysical methods to identify sinkhole hazards. The gravimetric method was the basic method for evaluating the geological and mining conditions in the area of the Piekary junction. It was used during the primary assessment stage to determine the sinkhole hazard levels and for final assessment of the effectiveness of the injection works. The seismic and borehole radar methods were used as complementary methods, and allowed the occurrence of voids and loosened zones to be specified. The electric resistivity method, due to the presence of metal ores, had limited application under these geological conditions. Exploitation of the metal ore deposits left an average of about $30 \%$ of those ores in the deposits, enough to distort the results of the electric resistivity surveys.

The positive effect of substrate treatment was the effective identification of voids and loosened zones in the rock mass by geophysical methods. Since the end of the treatment works in 2010, no discontinuous deformations have been observed to date at the Piekary junction. This proves that the substrate treatment has been effective. It should also be emphasized that the additional geotechnical structural protection included as part of the highway construction had a significant impact on securing the Piekary junction against the occurrence of discontinuous deformations $[2,3]$.

\section{References}

1. E. Popiołek, Z. Pilecki (eds.), Ocena przydatności do zabudowy terenów zagrożonych deformacjami nieciagtymi za pomoca metod geofizycznych (Assessment of areas threatened with discontinuous deformations for building suitability using geophysical methods). Wyd. IGSMiE PAN, Kraków (2005) (in Polish)

2. A. Miłkowski, Z. Pilecki, K. Kłosek, M. Tondera, Autostrada Al zaprojektowana na ,,dziurawym” podłożu, Cz. 1 (The A1 motorway designed on a "holed" ground, part 1). Magazyn Autostrady: budownictwo drogowo-mostowe 3/2010, 104-112 (2010).

3. A. Miłkowski, Z. Pilecki, K. Kłosek, M. Tondera, Autostrada Al zaprojektowana na ,,dziurawym” podtożu, Cz. 2 (The Al motorway designed on a "holed" ground, part 2). Magazyn Autostrady: budownictwo drogowo-mostowe 5/2010, 159-160 (2010).

4. Z. Pilecki, Methodology for A-1 motorway basement treatment effectiveness improvement by means of geophysical methods in the areas of metal ores shallow mining threatened with the sinkhole occurrence in the Upper Silesia, Gospod. Surowcami Min. 25(3), 319-331 (2009).

5. Z. Pilecki, Uzdatnienie podłoża autostrady A-1 na terenach pogórniczych płytkiej eksploatacji rud metali (Treatment of the A-1 motorway basement in post-mining areas of shallow mining of metal ore deposits), Studia, Rozprawy Monografie 184. Wyd. IGSMiE PAN, Kraków (2014).

6. Z. Pilecki, A. Kotyrba, Problematyka rozpoznania deformacji nieciagtych dla potrzeb projektowania konstrukcji drogowych na terenie ptytkiej eksploatacji rud metali (Problems of recognizing discontinuous deformations for the purpose of designing road structures in shallow metal ore mining), Prace Naukowe GIG 3/2007, 379-392 (2007). 
7. R. Czarny, Z. Pilecki, N. Nakata, E. Pilecka, K. Krawiec, P. Harba, M. Barnaś, 3D Swave velocity imaging of a subsurface disturbed by mining using ambient seismic noise, Eng. Geol. 251, 115-127 (2019) doi: 10.1016/j.enggeo.2019.01.017.

8. K. Krawiec, Z. Pilecki, Numeryczna symulacja procesu zapadliskowego $w$ warunkach geologicznych $i$ górniczych niecki bytomskiej na terenie pogórniczym płytkiej eksploatacji złóż rud metali (Numerical simulation of the sinkhole process in geological and mining conditions of the Bytom basin in the post-mining area of shallow mining of metal ore deposits), Technika Poszukiwań Geologicznych 1, 47-62 (2012).

9. E. Pilecka, Z. Pilecki, Analysis of relation between induced seismic activity and satelite data, $19^{\text {th }}$ Symp. on Application of Geophysics to Engineering and Environmental Problems SAGEEP, EEGS, 2-6 April 2006, Seattle, USA, 346-355 (2006).

10. E. Pilecka, D. Szwarkowski, An application of the ground laser scanning to recognise terrain surface deformation over a shallowly located underground excavation, E3S Web Conf. 24, 01006 (2017), doi: 10.1051/e3sconf/20172401006.

11. Z. Pilecki, Geophysical identification of voids and loosened zones in the shallow subsurface of post-mining areas, E3S Web of Conf. 66, 01001 (2018) doi: 10.1051/e3sconf/20186601001.

12. Z. Pilecki, E. Pilecka, J. Pszonka, J. Stanisz, J. Morman, Zagrożenia deformacjami nieciaglymi na obszarze górniczym Jaworzno III. (Discontinuous deformation hazard on the Jaworzno III mining area), Wyd. IGSMiE PAN, Kraków, (2012).

13. H. Marcak, Z. Pilecki, Assessment of the subsidence ratio be based on seismic noise measurements in mining terrain, Arch. Min. Sci. 64(1), 197-212 (2019) doi: $10.24425 / \mathrm{ams} .2019 .126280$.

14. P. Strzałkowski, Mathematical model of forecasting the formation of sinkhole using Satustowicz theory, Arch. Min. Sci. 60(1) 63-71, (2015) doi: 10.1515/amsc-2015-0005.

15. F. G. Bell, Land development. State-of-the-art in the location of old mine shafts, Bull. of the Int. Ass. of Eng. Geology 37, 91-98 (1988).

16. B. N. Whittaker, D. J. Reddish, Subsidence behaviour of rock structure, w: Comprehensive rock engineering - principles, practice and projects, J. A. Hudson ed., Pergamon Press, Oxford, New York (1993).

17. Z. Pilecki, The role of geophysical methods in the estimation of sinkhole threat in the post-mining areas of shallow exploitation in the Upper Silesian Coal Basin, Poland, Gospod. Surowcami Min. 24(3/1) 27-40 (2008).

18. Z. Pilecki, Z. Isakow, R. Czarny, E. Pilecka, P. Harba, M. Barnaś, Capabilities of seismic and georadar 2D/3D imaging of shallow subsurface of transport route using the Seismobile system, J. Appl. Geophys. 143, 31-41 (2017) doi: 10.1016/j.jappgeo.2017.05.016.

19. H. Marcak, Z. Pilecki, Some Geophysical and Geomechanical Remarks on Recognition Sinkhole Processes in Post-Mining Areas, Proc. 12 $2^{\text {th }}$ European Meeting of Environmental and Engineering Geophysics, 4-6 September 2006, Helsinki, Finland (2006).

20. www.gddkia.gov.pl and electronic presentations.

21. The map of the historical exploitation of metal ores „Karte Oberschlesischen Erzbergbauers - Herausgegeben von dem Koniglichen Oberbergamt zu Breslau - scale 1: 10000 . 